https://doi.org/10.18485/bogoljub_stankovic.2018.ch18

811.161.1'373.611:929 Станковић Б.

\author{
МИТРА РЕљИЋ \\ Универзитет у Приштини \\ са привременим седиштем у Косовској Митровици \\ Филозофски факултет \\ Катедра за руски језик и књижевност
}

\title{
БОГОљУБ СТАНКОВИЋ О СЛАВИСТИЦИ У ЧАСОПИСУ СЛАВИСТИКА
}

\begin{abstract}
У раду се, на основу прилога проф. Богољуба Станковића штампаних у различитим рубрикама Слависиике, даје скица његовог научног, наставног и организационог доприноса развоју славистике на размеђу двају миленијума. Утврђује се да радове Богољуба Станковића објављене у Славистиии, неовисно од предмета ауторове пажње (језичка и културна дезинтеграција словенског света, место славистичких друштава и организација у развоју славистике, конфронтационо проучавање словенских језика, настава инословенских језика и др.) и аспеката сагледавања проблема, обједињује актуелни, по словенске народе неповољан тренутак, те јединствена мисао и циљ - шта учинити да се растакање словенства заустави и стање у славистичкој науци поправи.
\end{abstract}

Кључне речи: славистика, Славистичко друштво Србије, диференцијација и дезинтеграција, настава језика, Богољуб Станковић: архивиста и хроничар свог времена

\section{Mitra Reljić}

\section{BOGOLJUB STANKOVIĆ ON SLAVIC STUDIES IN THE JOURNAL SLAVISTIKA}

Based on the articles of Professor Bogoljub Stanković published in various sections of the journalSlavistika, this paper gives a sketch of his scientific, teaching and organizational contributions to the development of Slavic studies at the turn of two millennia. It is found that the articles of Bogoljub Stanković published in Slavistika, regardless of the subject of the author's attention (linguistic and cultural disintegration of Slavic world, the place of Slavic societies and organizations in the development of Slavic studies, the confrontational research of the Slavic languages, teaching/learning another Slavic language, etc.) and the aspects of prob-

*hvostanskazemlja@gmail.com 
lem, are united by the current, unfavorable moment for the Slavic peoples, and the unique thought and goal ? to make the dissolution of the Slavic society stop and the situation in Slavic studies improved.

Key words: Slavic studies, Slavic Society of Serbia, differentiation and disintegration, language teaching/learning, Bogoljub Stanković: an archivist and chronicler of his time

Језичка и културна дезинтеграција, као пратећа појава глобализацијским процесима инициране десуверенизације националних држава, која је задесила словенски свет на измаку XX века, болно се одразила на сваког човека иоле упућеног у последице наведеног процеса, камоли слависту безмерно оданог својој струци. Покретање часописа Славис$\bar{u} u \kappa a$ 1997. године, за шта првенствена заслуга припада управо проф. Богољубу Станковићу, био је и најбољи одговор општеприсутним дезинтеграционим кретањима. ${ }^{1}$ У свакој од 15 књига Славистиике које су штампане за живота проф. Станковића препознаје се његово уредничко прегнуће и из сваке зрачи „његова неисцрпна енергија и безгранична љубав према модерно схваћеној словенској идеји, словенској култури, филологији и лингвистици..." (Терзић 2012: 17). До детаља упућен у рад Славистичког друштва Србије од самог његовог оснивања 1948. године, којем је, поред низа радова, посветио и посебну монографију (Станковић 2008), Богољуб Станковић је учинио све да реализује давнашњу намеру и жељу оснивача, као и свих каснијих чланова управе Друштва, да у циљу бољег остваривања задатака Друштва покрену часопис. Славис$\bar{u} u \kappa a$, чији се први број појавио уочи педесетогодишњег јубилеја Друштва, конципирана је баш онако како је часопис замишљао Радован Лалић три и по деценије раније - као научни, стручни, па и практични часопис који би упознавао слависте са новим истраживачким радовима, са оригиналним научним радовима, али и пружао информације о научном животу и развоју славистичке науке у словенским земљама (Станковић 1998: 13-14).

У петнаест бројева Слависииике објављених за његова живота, Богољуб Станковић је потписао укупно 54 прилога, распоређена у 8 различитих рубрика. У рубрици „Реферати” са редовних скупова слависта

1 „Часопис се појавио у ондашњим веома тешким приликама, кад се најмање могао очекивати, а и настао је под необичним околностима и у веома кратком интервалу од замисли до остварења. Рекло би се да је само провиђење допринело његовом настан-

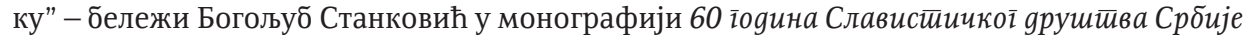
(Станковић 2008: 137) и у наставку описује те необичне околности настанка Славис-

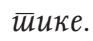


Србије нашло се 13 радова проф. Станковића, један - последњи његов

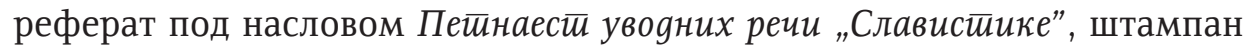
је у издвојеној рубрици - „Уводној речи”. У рубрици „Из славистичког живота” штампано је 25 текстова Богољуба Станковића, у рубрици „у свету славистичке литературе" - 4 (приказа књига), у рубрици „Српски језик у иностранству" - 2 прилога, у рубрици „Славистички архив" - 4, у рубрици „Славистичка баштина” (успостављеној уместо раније рубрике „Славистички архив") - 3, у тематској рубрици „Српско-чешке везе” - 1 и у рубрици „Научноистраживачки пројекти” - 1. Сами наслови рубрика, чији се број у Славистиии временом увећавао, као и чињеница да ниједну није лишио личне пажње, потврђује свеобухватност прегалаштва Богољуба Станковића на пољу славистике, произишле из његовог схватања да је за успешно превазилажење тешкоћа и истински развој славистике, поред научног рада, потребна и континуирана информисаност слависта о научној продукцији, о размени знања и искустава путем научних и стручних асоцијација, конференција, научних пројеката, о наслеђу претходних генерација слависта итд. Преокупације Богољуба Станковића у прилозима штампаним у часопису Славистиика тематски се крећу у два узрочно-последична смера: 1) актуелни положај словенских народа, језика и култура и 2) задаци и перспективе славистике. У оквиру сваког од ових шире узетих питања Богољуб Станковић је обрадио или дотакао читаву лепезу проблема и понудио мноштво решења.

Појава убрзане диференцијације и дезинтеграције словенских језика и култура, као негативна последица глобализацијских процеса, изнудила је потребу проф. Станковића, као и других лингвиста којима је до словенских језика стало, да се уз примарне области својих научних интересовања (синтаксе, граматике, лексикологије, лексикографије, наставе језика), у низу радова или деловима радова позабави и проблемима из домена социолингвистике. Тако у раду насловљеном Слависииика gaнас и суйра (Станковић 2005: 12-18) у целости посвећеном социолингвистичкој проблематици, Богољуб Станковић даје прецизну дијагнозу друштвене и политичке стварности у свету и исто тако прецизну скицу проблема на плану словенских језика и култура, очитованих у словенској језичкој и културној разједињености, пољуљаним идентитетима словенских народа, потискивању словенског двојезичја и вишејезичја, језичком сепаратизму на српском лингвистичком простору, прогону руског језика из српских школа, као последици русофобичне језичке политике итд. На другим местима Богољуб Станковић скреће пажњу 
на мрачне прогнозе језичких футуролога, на мање или веће опасности које су запретиле словенским језицима услед све видљивијег бројчаног редуковања њихових говорних представника, указује на лингвистички и културни колонијализам „кад се безобзирно настоји да доминантни светски језик потисне и замени матерњи, а да се успостављањем монопола једног језика успостави и монопол једног духовног и културног модела..." (Станковић 2000: 14). Надаље, говорећи о новој граници посред словенског света, тзв. сребрној завеси, те стварању културолошког простора „који се увелико подудара са границама некадашње Аустроугарске монархије”, Богољуб Станковић (2005: 13) констатује: „Истовремено у целокупном словенском свету, у већој или мањој мери се испољава поданички однос према Европи и Западу, који се највидљивије очитује у одрицању од свог културног и духовног иднтитета." Истичући апсурдност и противречност европских интеграционих процеса по рецепту „разједињавање ради уједињавања”, Богољуб Станковић закључује:

„И њихов (слависта - прим.) прави и истински допринос интеграцији Европе биће пре свега у залагању на свеопштем зближавању словенских народа, кроз ширење језика и упознавање култура. Само по себи се подразумева славистичко јединство кроз посебности, тј. најтешња сарадња свих слависта, без обзира којим се словенским језиком, књижевношћу и културом бавили. А да би тако и било, нопходно је њихово славистичко едуковање, што се посебно односи на словенске слависте у области националног језика, књижевности и културе. Они морају бити свесни да нису прави слависти ако сем матерњег не знају и још неки словенски језик, а у првом реду руски, и не познају и друге словенске језике и културе" (Станковић 2005: 15).

У низу фактора који илуструју актуелни положај и стање славистике а од којих зависи њена будућност, проф. Станковић посебно издваја: негативну демографску слику, тј. бројчано смањење словенске популације, неповољан тренд економског, културног и друштвеног развоја те нарушене међусловенске односе. Образлажући ово последње, Богољуб Станковић указује на трајуће тенденције разједињавања словенских народа па, последично, редуковања међусловенског двојезичја и вишејезичја, и подвлачи: „Парадоксално је да су се дезинтеграциони процеси у словенском свету одвијали истовремено са интензивним интеграционим процесима у Европи (...) Није могуће да се словенски народи интегришу са далеким и несродним, а да међусобно буду разједињени и супротстављени" (Станковић 2001: 10). ${ }^{2}$ Свако ко је лично познавао проф.

${ }^{2}$ Волети далеке народе а не волети сродне или свој народ пука је апстракција и крупна обмана. Љубав према далекима и далеком (казује нам то и старац Зосима Ф. Достојевског), таман као и љубав према Богу, могућа је само посредством ближњег. 
Станковића зна да је његово, у датом контексту изречено, „није могуће” садржавало најдубљу веру у супротно, тј. могуће, а на ползу словенства. ${ }^{3}$ Упркос вишедеценијском потискивању идеје словенске узајамности, што је кулминирало на размеђу двају последњих векова и двају миленијума, Богољуб Станковић је, имајући на уму двовековно прегалаштво плејаде најбољих слависта, почев од епохе словенског препорода (почетак XIX века) па до најновијег времена, чврсто веровао да идеја словенске узајамности „има перспективу блиставог оваплоћења” (Станковић 2004: 12). У процесу интегрисања Европе Богољуб Станковић (2001: 11) види прилику славистике да одигра корективну и комплементарну улогу, а не да буде инструмент за „краткотрајну или једнократну употребу па и злоупотребу у рукама власти". Услов за то јесте да се слависти у властитој делатности придржавају принципа научности, принципа узајамности и принципа свеобухватности (Станковић 2001: 11).

Нужност најширег едуковања, укључујући неговање словенског двојезичја и вишејезичја, посебно код слависта, јер само „широко славистичко образовање не допушта секташки приступ у славистичком деловању", Богољуб Станковић (2009: 47), ослањајући се на пример некадашњих великана српске славистике, образлаже принципом славистичке целовитости.

„Идеал Богољуба Станковића била је интегрална славистика, оличена у његовој девизи 'целовитост славистике у посебности'. Та девиза одраз је његовог погледа да посеб́ности славистичких субдисциплина и национално оријентисаних филолошких истраживања нису и не могу бити сметња интегралности кровне дисциплине. Ово, међутим, само уз услов да се никад не изгуби свест о целини, јер у супротноме прети феудализација славистичког царства, незналачко сужавање научне оптике, уситњавање интереса и интересовања - и, у крајњем исходу, потпуна негација самога смисла постојања славистике" (Буњак 2012: 63).

Уз принцип целовитости, Богољуб Станковић посебно истиче идеју словенске узајамности као кључни фактор очувања идентитета сваког словенског народа понаособ.

„Многодеценијска славистичка традиција нам показује да је иманентни циљ изучавања словенских језика (подразумева се ту и све оно што се језиком исказује и уобличава) у словенској средини достизање свести о томе да сваком словенском народу који се одрекне идеје словенске узајамности и словенства зарад тобожње своје посебности предстоји у релативно блиској будућности губљење не само општесловенског, већ и

${ }^{3}$ Оптимистичним прогнозама о „васкрсу словенства” проф. Станковић је не једном бодрио и аутора овог текста. 
оног посебног идентитета. Уосталом, славистика је умногоме и настала пре два века да би бранила како општи тако и посебне словенске идентитете" (Станковић 2009: 47).

У успеху сваке појединчне славистичке дисциплине - србистике, русистике, бохемистике и др., под напред поменутим условом који подразумева свест о целини, Богољуб Станковић је видео корист за све заједно. И обрнуто, развијена и јака интегрална славистика сигурно је окриље појединачним славистикама.

Текстови Богољуба Станковића објављени у првих 15 бројева Славистике потврђују виђење Богдана Терзића (2012: 17) да је за остваривање задатака славистике и њене боље перспективе, Богољуб Станковић сматрао подједнако важним наставни, научни, организациони и издавачки рад. Следствено томе, он посеб́у пажњу посвећује настави словенских језика, сугерише нов приступ изучавању словенских језика као инословенских. У низу стратегија које би поправиле незавидан положај славистике на почетку новог миленијума, Богољуб Станковић (2000: 11) нуди могућност словенског приближавања „као један од предуслова да се сачува идентитет словенских језика и култура пред налетом туђег духа и друкчијег поимања света". У том смислу сугерише разраду функционалне стратегије која подразумева свеж приступ методама учења страних језика, интензивирање међусловенских превода уметничке прозе и поезије, публицистике и научних дела (Станковић 2000: 11). Инсистирајући на новом приступу изучавању словенских језика као инословенских, Богољуб Станковић (2005: 16) полази од незаобилазног тренутка („духа времена”) „који подразумева ефикасност, интензивност, функционалност и рационализацију. Прилагођавања тим захтевима времена морала би се извршити у целокупном систему организације и реализације наставе који, између осталог, обухвата: план и програм, циљеве и задатке, наставне методе, наставна средства, уџбенике и приручнике, приступе и облике наставе и сл.".

У низу изнетих принципа, Богољуб Станковић не једном подвлачи и принцип дидактичке целовитости језика, књижевности и култуpe, посебно важног за изучавање српског језика у иностранству који је, претходном језичком разградњом и успостављањем политичких језика, изложен бројним манипулацијама.

„Применом принципа дидактичке целовитости језика, књижевности и културе странци који изучавају српски језик штите се од нетачне идентификације ијекавског изговора са хрватским или бошњачким језиком и 
пружа им се објективна и научна информација о српским књижевним и културним вредностима, која је веома потребна сада кад се са супротне стране чак и Мирослављьево јеванђеље на Интернету представља као хрватско" (Станковић 1999: 284).

Седам прилога проф. Станковића у рубрикама „Славистички архив" и „Славистичка баштина”, документованих архивском грађом, поред оних објављених у рубрици „Реферати”, сугеришу потребу и важност ослањања на достигнућа претходних генарација слависта (Cagaшюости

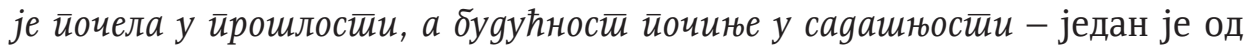
Станковићевих наслова), али и пропуста те нереализованих идеја које је, по мишљењу Богољуба Станковића, ако и са закашњењем, увек могуће реализовати. Тако нас у једанаестом броју Славистике и у рубрици „Славистичка баштина” Богољуб Станковић подсећа на никад реализовану обавезу југословенских слависта да израде Истиорију слависиике gруіе йоловине 19. века а у оквиру заједничког пројекта договореног на Седмом међународном конгресу слависта у Варшави 1973. године. И као што је остварио полувековну жељу управе Славистичког друштва Србије да покрене часопис, Богољуб Станковић и у овом случају приступа са вером и оптимизмом, па каже:

„Не улазећи у разлоге зашто се овако амбициозна замисао није онда утемељила, сада ћемо само констатовати да ништа од онога што се елаборатом предвиђало није реализовано (...) Али остала је документација о том хтењу и остала је да живи идеја као још једна потврда о неугасивости замисли која је једном настала. Доказ томе је заснивање пројекта 'Српска славистичка баштина' у оквиру Славистичког друштва Србије и отварање рубрике 'Славистичка баштина' у часопису Слависиика. Садашњим и будућим славистичким посленицима пружа се прилика да оживотворе неостварене замисли и хтења својих претходника." (Станковић 2007: 365).

Говорећи о интегралној славистици као идеалу Богољуба Станковића, Петар Буњак (2012: 63) даје приказ и његових оргнизаторских способности:

„Овом свом идеалу Богољуб Станковић тежио је првенствено радом на организовању славистичког научног живота и канала за посредовање славистичких информација. А погодан оквир за то било је управо Славистичко друштво Србије. Није штедео Богољуб Станковић своје снаге на организационим пословима. Под окриљем Друштва организовао је увек на време и увек беспрекорно, мноштво семинара за наставнике, редовних националних славистичких окупљања, на десетине међународних трибина, колоквијума и конференција. Опет, по његовом уверењу, ништа од тих подухвата не би имало правога смисла, уколико за собом не би оставило опипљив траг - у виду штампаних публикација. Зато је изузетан 
значај придавао славистичкој научној периодици, повременим и посебним издањима."

Напоменућемо да је, поред часописа Слависииика, Богољуб Станковић покренуо и часопис Русский язык как инославянский те научну едицију Славистичика библиойека. Ако се овоме дода читав низ серијских публикација, зборника и монографија у издању Славистичког друштва Србије а под руководством проф. Станковића, онда не изненађују речи проф. Богдана Терзића (2012: 19) да је на пољу издаваштва „Он (је) успео да оствари оно што никоме на Катедри за славистику и у Славистичком друштву није пошло за руком". У биобиблиографском чланку о Богољубу Станковићу његове организаторске способности, између осталог, посеб́н истиче и проф. Предраг Пипер (2011: 610-616), наводећи да је под руководством Богољуба Станковића Славистичко друштво Србије, поред организовања више славистичких скупова и штампања зборника са тих скупова, обновило плодну сарадњу са другим сродним установама и удружењима, установило награду „Павле Ивић” и др.

Број (25) и врста прилога Богољуба Станковића у рубрици „Из славистичког живота" потврђује колики је значај придавао размени славистичких информација и упознавању слависта са активностима, тежњама, постигнућима и пропустима на пољу славистичке науке и струке. Као неуморни сакупљач драгоцене архивске грађе, ставио је себи у задатак да буде и хроничар времена садашњег, не би ли поколењима која долазе обезбедио непрекинути историјски след славистичке науке и струке, посебно српске. Богољуб Станковић је брижљиво бележио припреме научних скупова, конгреса, конференција, научних форума широм словенског света, њихову реализацију и научне одјеке, јубилеје научних и стручних удружења и асоцијација, одавао признање најзаслужнијима - Радовану Лалићу, Ђорђу Живановићу, Драгутину Мирковићу, Богдану Терзићу, Витомиру Вулетићу, и не само њима. На страницама Слависиике Богољуб Станковић је изнимну пажњу посветио славистичким организацијама - њиховим задацима и могућим дометима. О томе сведоче и његови прецизни и свеобухватни годишњи извештаји о раду Славистичког друштва Србије чији је председник био. Искуство председника Славистичког друштва Србије додатно је оснажило његово уверење да је за равноправан положај словенских језика и култура у Европи од посебног значаја: а) интензивирање рада постојећих међународних славистичких асоцијација; б) стварање нових међународних славистичких асоцијација; в) интензивирање рада земаљских славистичких организација; г) развијање веза и сарадње славистичких организација (Станковић 2001: 12). У погледу успеха тих организација, Богољуб Станковић (2005: 16) каже: „Уколико су мање догматске и окоштале, бране научну истину засновану на објективним 
чињеницама, облике и садржаје свог деловања креативно усавршавају и прилагођавају духу времена, утолико ће њихов допринос будућем развоју славистике бити плодотворнији и значајнији."

Радове проф. Богољуба Станковића објављене у Слависиииии, неовисно од предмета ауторове пажње (језичка и културна дезинтеграција словенског света, место славистичких друштава и организација у развоју славистике, конфронтационо проучавање словенских језика, настава инословенских језика и др.) и аспеката сагледавања проблема, обједињује актуелни, по словенске народе неповољан тренутак, те јединствена мисао и циљ - шта учинити да се растакање словенства заустави и стање у славистичкој науци поправи. У том смислу, свакој анализи претходи прецизно спецификовање проблема, његови узроци и могуће последице, а следе научно засновани и завидним педагошким искуством оснажени предлози и препоруке. Добро би било да се тих предлога и препорука чешће присетимо и да нам несебично прегалаштво проф. Станковића на пољу и у интересу славистике буде пример за властито делање и поступање.

\section{Цитирана литература}

Буњак Петар. „50 скуп слависта у знаку сећања на Богољуба Станковића”, Славистичка XVI, 2012: 61-65.

Пипер Предраг. Прилози историје српске славистике: биобиблиографска грађа. Београд: Чигоја, 2011.

Станковић Богољуб. „Место Славистичког друштва Србије у развоју српске славистике друге половине XX века". Славистиика II, 1998: 7-16.

Станковић Богољуб. „Актуелни проблеми изучавања српског језика у иностранству". Слависиикка III: 1999: 281-284.

Станковић Богољуб. „Ка функционалној стратегији изучавања и проучавања словенских језика". Славистиика IV, 2000: 11-16.

Станковић Богољуб. „О будућности славистике и славистичких организација”. Славистиика V, 2001: 9-15.

Станковић Богољуб. „Два века славистичког истрајавања на грађењу и очувању

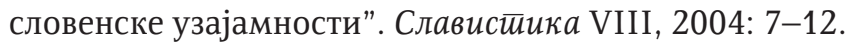

Станковић Богољуб. „Славистика данас и сутра”. Славистиика IX, 2005: 12-18.

Станковић Богољуб. „Један покушај заснивања научноистраживачког пројекта из историје српске славистике". Славистика XI, 2007: 363-366.

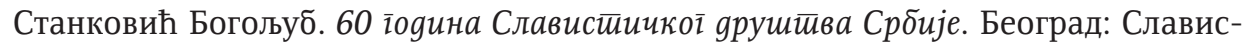
тичко друштво Србије, 2008.

Станковић Богољуб. „Традиција и савремено изучавање словенских језика”. Слависиика XIII, 2009: 45-49.

Терзић Богдан. „Неуморни прегалац на пољу славистике (Проф. др Богољуб Станковић, 1938-2011)". Славистиика XVI, 2012: 17-20. 


\section{Митра Релич}

\section{БОГОЛЮБ СТАНКОВИЧ О СЛАВИСТИКЕ В ЖУРНАЛЕ СЛАВИСТИКА}

\section{Резюме}

В работе указывается на вклад профессора Боголюба Станковича в развитии славистики в научном, педагогическом и организационном планах. Выявляется, что независимо от предмета авторского внимания (языковая и культурная дезинтеграция славянского мира, место славистических обществ и организаций в развитии славистики, сопоставительное изучение славянских языков, обучение инославянским языкам и т. д.) и исследовательских подходов, работы Боголюб̃а Станковича, опубликованные в Славистиике, главным редактором которой был сам профессор Станкович, характеризует актуальное неблагоприятное состояние славянских языков и культур и единственная мысль - как остановить дезинтеграционные процессы и улучшить статус славянских народов, их языков и культур.

Ключевые слова: славистика, Славистическое общество Сербии, диференциация и дезинтеграция, языковое обучение, Боголюб Станкович: архивист и хроникер своего времени 